\title{
Water Allocation Computation Model for River and Multi-Reservoir System with Sustainability- Efficiency-Equity Criteria
}

\author{
Anang M. Farriansyah ${ }^{1, *}$, Pitojo Tri Juwono ${ }^{2}$, Ery Suhartanto ${ }^{2}$ and Very Dermawan ${ }^{2}$ \\ 1 Civil Engineering-Doctoral Program, University of Brawijaya, 65145 Malang, Indonesia \\ 2 Water Resources Engineering, University of Brawijaya, 65145 Malang, Indonesia; pidiaa@yahoo.com (P.T.J.); \\ erysuhartanto@ub.ac.id (E.S.); veryderma@gmail.com (V.D.) \\ * Correspondence: anangmf62@gmail.com
}

Received: 24 July 2018; Accepted: 25 October 2018; Published: 28 October 2018

\begin{abstract}
Limitation and inequality of water in interspace and time opposite to the increased water demand indicated from the density of headwork nodes in the river system. It requires proportional-equal water allocation determined by the model. Existing models are not based on water as a public good and not using the sustainability-efficiency-equity criteria despite irrigation is the biggest use. The Water Allocation Model Equalization or in Indonesian it is called "Model Ekualisasi Alokasi Air" (MEQAA) is proposed. MEQAA modeling system is inspired by the shortage of irrigation water for a quite extended period of time and the complexity of the water allocation system in the Lombok river basin. MEQAA is assisted by MS Excel-VBA 2016 that can be tracked automatically on an independent river system scheme to create a network equation with mass balance principle and operation rule. This model is based on the dynamic-deterministic, so the performance test can be used with synthetic data. This experiment was compared with the output from the equalization method and the "first-come, first-served" (FCFS) method. The conclusions of this experiment are: (a) MEQAA can build a specific model according to a network-flow configuration for optimization-simulation with iteration of K-factor (release portion) and C-factor (storage portion) in order to get a maximum and equal and (b) the FCFS method can be detrimental to the river system. MEQAA is suggested as a decision support tool for water allocation planning or real-time operation.
\end{abstract}

Keywords: C-factor; iteration; K-factor; network equation; river scheme

\section{Introduction}

Water deficit becomes a problem in the irrigation sector in Indonesia, as it uses up more than $90 \%$ of the total water demand, and therefore it is necessary to limit water [1]. The water deficit is becoming more severe due to selfish water users, which leads to the inequality of water allocation, due to weak government control [2]. Furthermore, water allocation planning is not supported by suitable models to achieve common goals and reduce conflicts [3,4]. Water as a public good should be allocated equally, with the priority of daily necessities and agricultural irrigation [5]. However, water allocation practices have not been system-based and have not yet been emphasized to the triangle of UN Water criteria, which is simultaneous sustainability-efficiency-equity [6], for mutual benefit in the system [7].

Software packages of modeling systems such as RIBASIM (Deltares, Delft, Netherland), REALM (Victoria University of Technology, Melbourne, Australia), WEAP (Stockholm Environmental Institute, Stockholm, Sweden), MODSIM (Colorado State University, Colorado, USA), and WRAP (Texas A\&M University, Texas, USA) are user-friendly tools for water allocation planning with the orientation in demand priority. The models mentioned above are decision support tools based on the deterministic 
model; they are integrated with hydrological analysis and water quality. Further details about comparative studies of these models can be found in [8-11].

However, other modeling systems such as RIBASIM cannot produce an optimum volumetric release in inter-headwork nodes, and they are not approriate with the Indonesian government regulations [12]. Moreover, considering the irrigation sector as the main support of food security and as the largest water user [1], the irrigation water allocation has to be managed with the sustainability-efficiency-equity criteria. Regarding the gap, MEQAA ("Model Ekualisasi Alokasi Air") is a computation model for internode water distribution (similar users) in the river system $[13,14]$.

MEQAA accommodates the UN Water criteria [6] with simplified elaboration, which are (a) sustainability, as the security of water, food, and environment/ecosystem with equal priority; (b) efficiency, as utilization in accordance with water demand and availability in order to maximize the release; and (c) equity, as equality of water in internode and time. To meet these criteria, MEQAA performs an equalization of water allocation portions, by integrating that as the main constraint.

From this research [8-11], all of the other models mentioned above are not integrated with sustainability, efficiency, and equity criteria as constraint and not calculated directly (requiring much input). Their model characteristics are: (a) a water allocation plan with the first-come-first-serve method; (b) a decision support system on a watershed basis, and integrated with hydrology analysis and so on, requiring much more input data than the water allocation solution itself $[15,16]$; (c) not being simple and requiring a professional operator and long negotiation [11]; and (d) not considering the ability among reservoirs, causing the operational problems in the future [17]. These model outputs do not fulfill the Indonesian government's regulation that prioritizes proportional and equal water allocation, including the ecosystem needs, so they are difficult to put into practice.

The idea of MEQAA comes from the need to equate water distribution by using the K-Factor (release/demand ratio) indicator in the Lombok river basin (RB) [18]. The Lombok river basin was chosen as the modeling inspiration, because: (a) there are suppletion channels for wet-dry rivers, with weir/diversion and multi-reservoirs (with average density 1 node $/ 4 \mathrm{~km}^{2}$ ) [19]; (b) the area is known as a paddy surplus zone, despite irrigation water deficit still happening in most of the watershed (demand/available ratio more than 200\%) [20]; and (c) the survey result of the $\mathrm{K}$-factor class in inter-irrigation areas is unequal, because the withdrawal of water has not yet been controlled/measured [12,21].

From global conditions of water balance and the uniqueness of the utility of river systems in the Lombok river basin, as well as limited preliminary MEQAA capabilities in a simple system [12], further research has the aim that MEQAA can be applied generically in a complex independent river system, with multi-reservoir and suppletion channel/double estuary. The idea of making MEQAA as a generic model was conceived because: (a) the preparation of procedures and mathematical functions do not need to be repeated in every system modeling [10] and (b) this negates human error while compiling water balance and optimizing the equation manually throughout the various systems.

Another objective, is that MEQAA is able to calculate water allocation with the indicator of release portion (K-factor) and storage portion (C-factor) based on sustainability-efficiency-equity criteria. MEQAA will equalize the supply/demand in interspace and time, including: (a) inter-user with K-Factor; (b) inter-reservoir with C-factor; and (c) between end period volume of the current operation and anticipated volume in the next period. For this solution a linear program is used, because it is widely used as an optimization of water allocation in river and reservoir systems [7,10,22,23]. The optimizations of MEQAA are solved by simulation of progressive iteration algorithm [24], for optimal/approximate output value [10]. The optimization simulations will solve linear and nonlinear aspects in multi-reservoirs, so it is suitable for water allocation solutions in a complex system [8,24-26].

This paper presents the latest MEQAA computation experiments using synthetic data based on the characteristics of the Lombok river basin. Furthermore, the outputs of two water allocation methods are compared between equalization and first-come-first-serve (FCFS). FCFS is one of the water allocation methods that have long been used and widely practiced for irrigation in Indonesia [20]. In the future, 
MEQAA is expected to become the core of water allocation planning to support centralized control of real-time operation based on feedback from operators on the field.

\section{Modeling Concept}

\subsection{Equalization of Water Allocation Portion}

UN Water emphasizes the integrated water resources management (IWRM) guideline of sustainability-efficiency-equity criteria [6] that is appropriate with Indonesian regulations [5]. In water allocation practice, the triangle of these criteria can be elaborated as: (a) sustainability emphasizing equal priority between food security and environmental resilience/ecosystem; (b) efficiency emphasizing the use of sufficient water according to water requirements and water availability potential; and (c) equity emphasizing equality of water allocation portion in upstream-downstream and wet-dry rivers [12]. All three are accommodated in MEQAA.

In the context of social welfare, water allocation can be measured by equality of supply/demand proportionately [27]. The proportional approach is largely practiced on irrigation in many countries [28]; it is the provision of water according to individual needs. The definition of K-factor as the weight of the water allocation is the supply/demand ratio which can be found in $[10,11,28]$. K-factor indicates (a) volumetric reliability of water allocation in the system [29] and (b) schedule of water distribution in the irrigation area $[30,31]$.

Water should be allocated equally among similar users in the system [11]. Water allocation control is the transference of surplus water to other parts of the system so there is no decrease in productivity [28]. Water distribution in the river is done to realize the allocation of water that has maximum discharge with the same K-factor. Controlling each node in the river will have an impact on the operation in the irrigation area, so the K-factor classification is required. The class of $\mathrm{K}$-factor in Table 1 is based on irrigation practices in the Lombok river basin [21].

Table 1. K-factor standard for irrigation operation.

\begin{tabular}{ccccc}
\hline Class & Range of K-Factor (\%) & Deficit & Operation Categories & Interlude of Water Distribution \\
\hline K1 & $80-100$ & Zero-Very low & Continuous & - \\
K2 & $60-79$ & Low & Rotation 1 & Short \\
K3 & $40-59$ & Medium & Rotation 2 & Medium \\
K4 & $20-39$ & High & Rotation 3 & Long \\
E & $0-20$ & Very high & Emergency & Priority is inter-irrigation areas \\
\hline
\end{tabular}

If a user obtains water allotment with a similar value to a K-factor, it means that the interspace of using water can be called equal. In addition to K-factor as an indicator of water adequacy at the user level, C-factor is needed as an indicator of storage portion for water distribution in multi-reservoirs. Water cannot be claimed by one reservoir but must be distributed among reservoirs in the system. If the inter-reservoir has the same $\mathrm{C}$-factor, then the interspace that serves to hold water can be called equal. Furthermore, water is not only needed for the moment, as anticipation of the future is necessary, which concerns the final volume in the reservoir being needed as inter-time inventory. This anticipated volume is the expected final volume, calculated from period to period based on the predicted hydrological conditions or approached from the planned reservoir rule curve. MEQAA will make equalization of K-factor, C-factor and K-factor, and C-factor as a guarantee of operational sustainability.

Equalization will make water allocation result in sync with triangle criteria, and the operation rule as the policy decision is that: (a) water distribution from upstream to downstream is in hydraulic-gravity; (b) if water is at a surplus (K-factor $=100 \%$ ) then the reservoir is prioritized to store water so C-factor $\geq 100 \%$; (c) if water is sufficient to limit $(40 \%<\mathrm{K}$-factor $<100 \%)$, then the release/spill flow/discharge contribution is adjusted so that K-factor and C-factor are equal or user priority are equal to reservoir storage; (d) if water is very limited (K-factor $<40 \%$ ) then the outflow from the reservoir is set so that $\mathrm{K}$-factor $>\mathrm{C}$-factor or user priority is more than reservoir storage, with 
K-factor equal and C-factor equal; and e) for the anticipated volume of operations in later periods, the outflow from the reservoir is adjusted so that the $\mathrm{K}$-factor $\approx \mathrm{C}$-factor or current operating priority is equal to the future period. Meanwhile, in emergency conditions due to drought (K-factor $<20 \%$ ), it is recommended to implement on-off rotation internodes, in order to increase K-factor. The selection of nodes in the on-off rotation is determined based on the risk level priority in every node [28].

\subsection{River System Categories}

MEQAA was inspired by the water allocation system in Lombok river basin [21] (Figure 1) (3.43 million people, 197 watersheds, $4738 \mathrm{~km}^{2}$, rainfall 213-3153 mm/year, evaporation 2.23$6.26 \mathrm{~mm} /$ day). The potential of surface water availability in the river basin is 2.978 million $\mathrm{m}^{3} /$ year; the sources are mostly from Lake Segara Anak in Mount Rinjani (+3726.00 m) and the water requirement is 2809 million $\mathrm{m}^{3}$ /year (96\% for irrigation). Moreover, there are 186 weirs/diversions and 26 "embung" (small dam) in 40 independent rivers for 35,333 ha irrigation areas and 12 interconnection rivers with 310 weirs/diversions, 74 small reservoirs, and three reservoirs (dam) (capacity 23-26 million $\mathrm{m}^{3}$ ). $\mathrm{In}$ the interconnection system, there are two suppletion channels (high-level diversion or HLD) with a total length of $60.28 \mathrm{~km}$. Both of these channels transfer water from wet waters $\left(4-12 \mathrm{~m}^{3} / \mathrm{s}\right)$ in western Lombok to dry watersheds in central Lombok, east Lombok to south Lombok for 97,797 ha irrigation area. For example, most nodes are found in Dodokan River (dry river category) with 82 nodes which have 25 small reservoirs and two reservoirs.

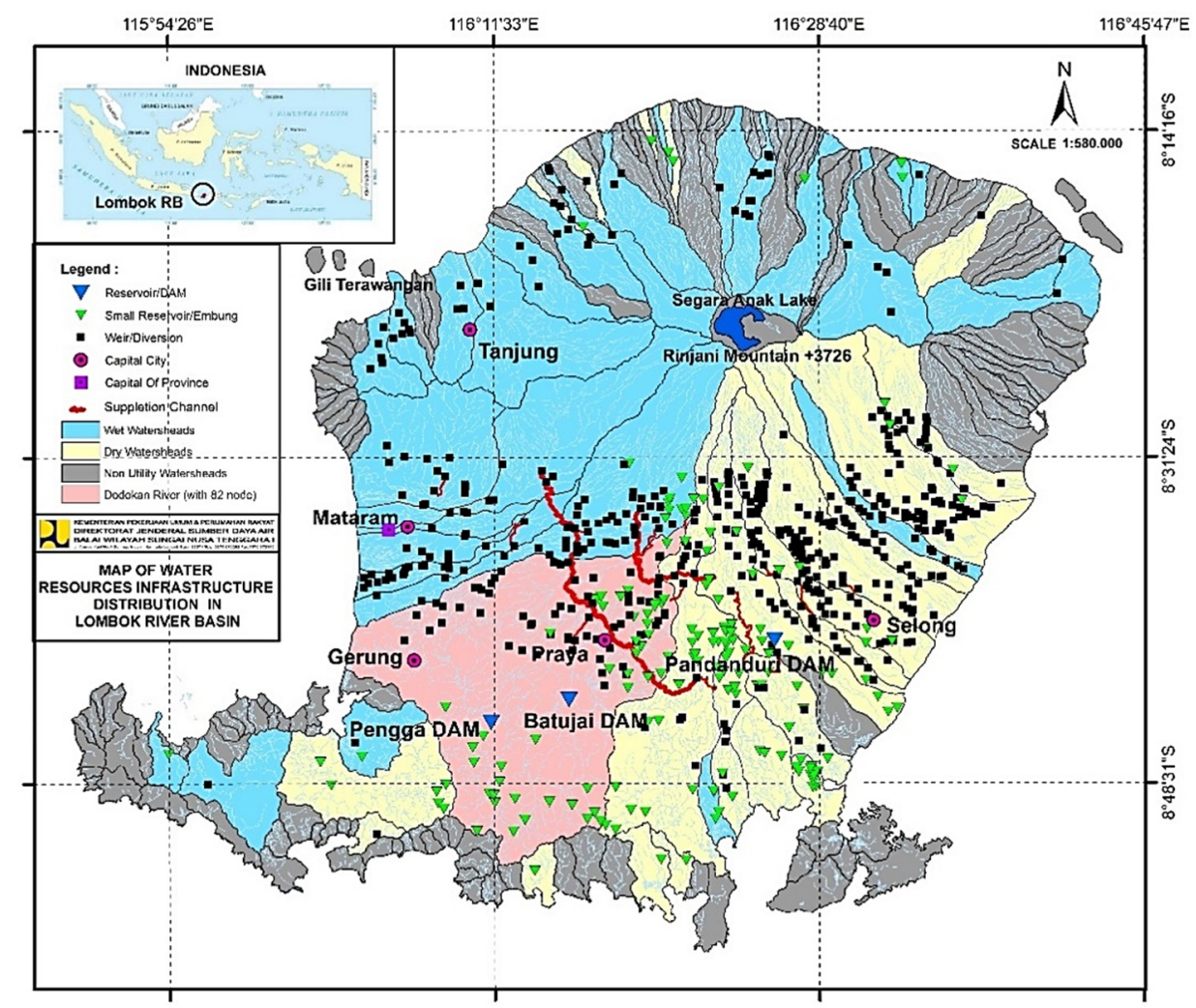

Figure 1. Lombok river basin with headwork nodes distribution.

52 watershed utilities $\left(3486 \mathrm{~km}^{2}\right)$ can be categorized as river system structures containing headwork nodes as in Figure 2. Each independent river can consist of one or more nodes of diversion and reservoirs. The rivers have wet and dry hydrological conditions. To make the water distribution smooth, they can be connected via suppletion channels to become interconnected, that is, interdependent between two rivers and interdependent among more than two rivers. 


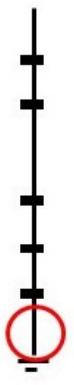

(a)

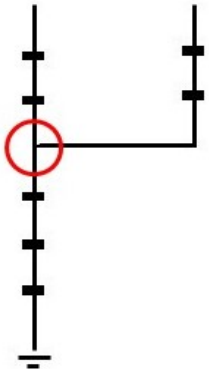

(b)

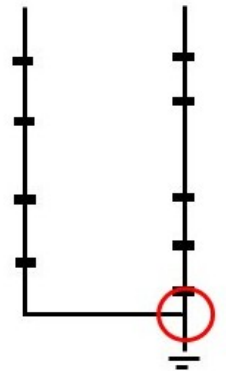

(c)

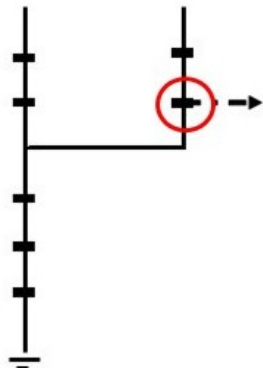

(d)

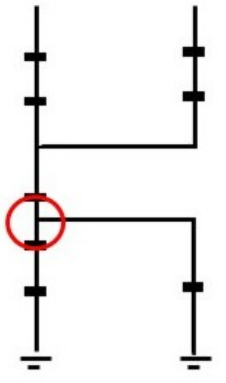

(e)

Figure 2. River system type categories in Lombok river basin. (a) Single trajectory type; (b) Connected trajectory type, tributary with one most downstream node on the main river; (c) Unconnected trajectory type, the most downstream nodes of the tributary do not connect upstream to the most downstream nodes in the main river; (d) Suppletion channel type, river with suppletion channel; (e) Double estuary type, river with double estuary. The red circle is a type of category.

\subsection{Network-Flow Node}

MEQAA using the principle of mass balance equation $[10,22,25]$ is:

$$
I-O=\Delta V
$$

Network Equation (NE) will be compiled based on Equation (1) in each node as a model object as shown below.

In Equation (1) and Figure 3 there are: (a) input (I) from upstream which is local inflow or spill flow; (b) input (I) from left/right that is local inflow spill flow/contribution from suppletion channel; (c) output $(O)$ to the downstream for the next node; and $(\mathrm{d})$ output $(O)$ to left/right which is release/contribution to suppletion channel. The input and output deviation is notated as delta storage $(\Delta V)$ at a specific time step $(\Delta t)$, are $\Delta V=0$ (weir/diversion) and $\Delta V \neq 0$ (reservoir) [10,22]. Basically, $\mathrm{NE}$ contains variables in Equation (1), and it is useful for optimization-simulation of water allocation in the system.

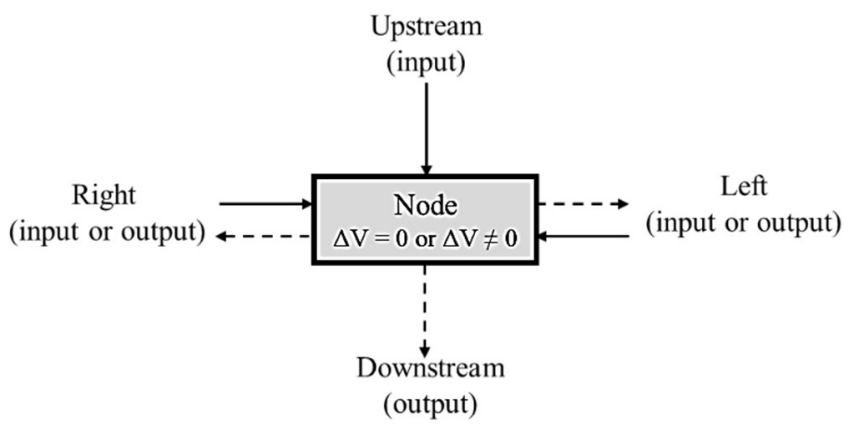

Figure 3. Input-output balance in headwork node.

NE arrangement follows the domino effect of the flow [10,32]. NE is formed by linking up the water balance equation internodes which are connected hydraulically-gravitationally through the link/reach in each river reach (RR). Each river consists of one or more river reaches, depending on the tributary. For example, in Figure 4 is a river scheme (a) as a transformation of the watershed map (b). In this scheme, there are three river reaches, one main river and two tributaries with domino effect that are: (a) at RR 100 across nodes 1-2-3-4-5; (b) at RR 200 across nodes 6-7-3-4-5; and (c) at RR 300 across nodes 8-9-5, so the system formed trajectories of 1-2, 6-7, 3-4, 8-9, and 5. Network-flow node in MEQAA preliminary [12-14] has been confirmed with the concept of upstream to downstream computational sequencing in the control points [10]. 


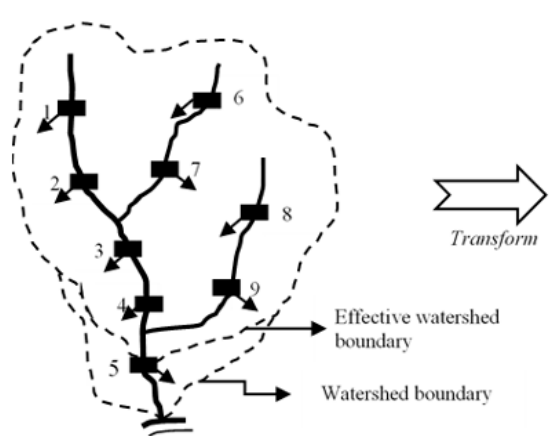

(a)

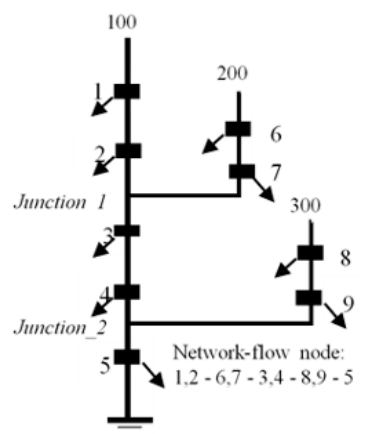

(b)

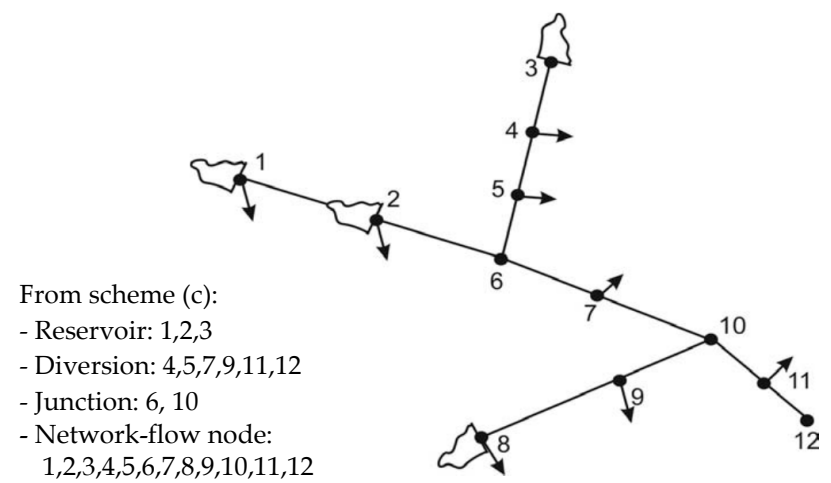

(c)

Figure 4. Transformation sketch from map to the scheme in Independent River. (a) Watershed map with headwork nodes; (b) River scheme (MEQAA version); (c) River scheme (Wurbs version).

\subsection{Optimization-Simulation}

Water allocation objective function in the river system which maximizes release at each node is:

$$
\text { Total } Q R=\max \sum_{i=1}^{n} Q R i
$$

For the elaboration objective function, the simple sketch (Figure 5) informs the mathematical relationship on inter headwork (HW) node through the link or reach within the river reach (RR). Each spill flow from the upstream node affects the water availability in the downstream node.

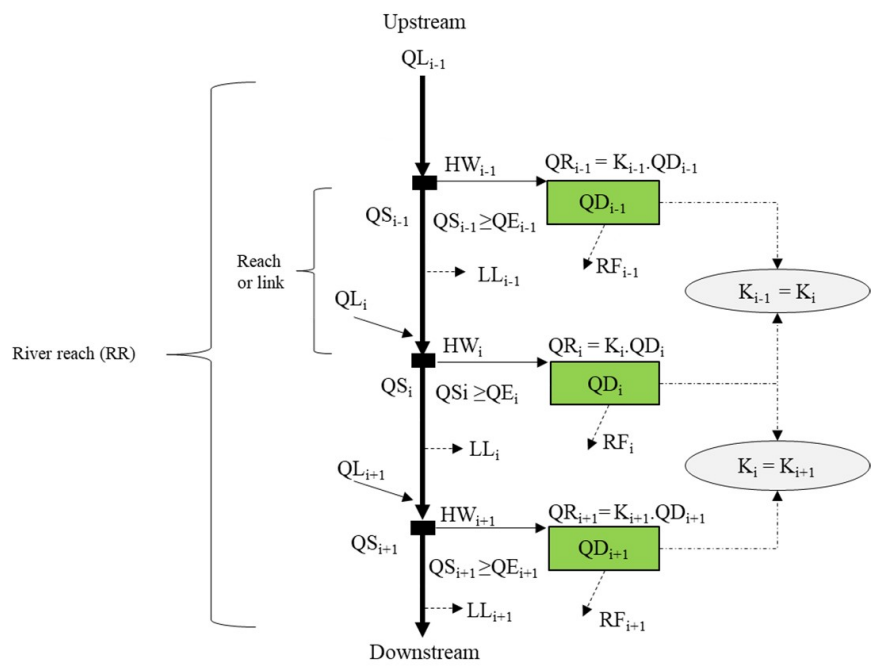

Figure 5. Variable in network-flow node trajectory. 
The following MEQAA constraints will integrate: (a) sustainability, represented with ecosystem quota that has to be served from spill flow continuously; (b) efficiency, represented with a release $\leq$ demand and K-factor as the index of water adequacy; and (c) equity, represented with a volumetric equality, being that the K-factor and C-factor of nodes must be equal in inter-time and space.

Constraint equations for linear optimization $[10,33]$ according to water allocation concept in Figure 5 are:

1. Water Availability The total available water $(Q A)$ is described as local inflow $(Q L)$ and spill flow / contribution from upstream node $\left(Q S_{i-1}\right)$ is then:

$$
Q A_{i}=Q L_{i}+Q S_{i}
$$

$Q L$ depends on hydrologic factors from the inter node catchment area.

2. Ecosystem Quota Sustainability of irrigation operations leads to food security and ecosystem sustainability has an impact on environmental stability. Both are important, so they must be integrated [6]. Spill flow in each node must meet the ecosystem water need for sustainable environment $[7,34]$ or $Q S_{i} \geq Q E_{i}$ criteria. The environmental water requirements of rivers in Iran are $10 \%$ (October-March) and 30\% (April-September) of water availability [6], while MEQAA is in line with regulations in Indonesia [35] as:

$$
Q E_{i}=5 \% \cdot Q A_{i} .
$$

3. Efficiency The efficiency criterion is a release $\left(Q R_{i}\right)$ which is not exceeding demand $\left(Q D_{i}\right)$ or 0 $\leq Q R_{i} \leq Q D_{i}$ [36]. If the elements $0 \leq Q R_{i} \leq Q D_{i}$ are divided by $Q D_{i}$, then $0 \leq K_{i} \leq 100 \%$ or release portion is:

$$
K_{i}=\frac{Q R_{i}}{Q D_{i}} 100 \%
$$

Equation (5) is identical to $Q R=K$. $Q D$ meanwhile $Q R \leq(Q A-Q S)$. $K$ will be classified according to Table 1 for operational information in the irrigation area. Criterion of utility of water available reviewed in the most downstream node. If $K<100 \%$ then $Q S \approx Q E$, and if $K=100 \%$ then $Q S \geq Q E$.

4. Reservoir Operation

- Reservoir operation rule is derived from mass balance in Equation (1) [10,22,37], which for each node is:

$$
V_{c a l}=V_{\text {beg }}+V_{\text {in }}-V_{\text {loss }}-V_{\text {rel }}-V_{\text {spill }}
$$

with $V_{c a l}=$ calculation volume, $V_{b e g}$ and $V_{\text {end }}$ denote the storage volume at the beginning and end, $V_{\text {in }}=$ inflow, $V_{\text {loss }}=$ losses, $V_{\text {rel }}=$ release, $V_{\text {spill }}=$ spill flow, and $V_{\text {eff }}=$ effective capacity. Outflow in Equation (6) is based on boundary $0 \leq V_{\text {end }} \leq V_{\text {eff; }}$, that is, if $0 \leq V_{\text {cal }} \leq$ $V_{\text {eff }}$ (normal), then $V_{\text {end }}=V_{\text {cal }}$, and if $V_{\text {cal }}>V_{\text {eff }}$ (spill out), then $V_{\text {end }}=V_{\text {eff. }}$.

- Based on Equation (6), future periods of operation need to anticipate volumes $\left(V_{\text {stock }}\right)$ which is based on the reservoir rule curve. Storage portion (C-factor) in Equation (7) is an indicator of $V_{\text {end }}$ achievement of $V_{\text {stock }}$. $V_{\text {stock }}$ is the $V_{\text {end }}$ which is expected to be achieved from the current operation. If water is limited, then $0 \leq C_{i}<100 \%\left(V_{\text {end }} \leq V_{\text {stock }}\right)$ and if it is at a surplus, then $C_{i} \geq 100 \%\left(V_{\text {end }} \geq V_{\text {stock }}\right)$.

$$
C_{i}=\frac{V_{\text {end }}}{V_{\text {stock }}} 100 \%
$$

- Rule curve operation is assumed to be cyclical to a certain pattern [38]. The rule curve pattern corresponds to a non-linear function that can be constructed through optimization- 
simulation based on time series data [34]. This curve can be produced by using the regression method [39]. Rule curve can be transformed into a rule curve coefficient (CRC), such as a sinusoidal curve to facilitate the calculation of the mandatory $V_{\text {stock }}$ period $(t+1)$. In this MEQAA experiment with single data, the boundary $C R C$ is derived from $0 \leq V_{\text {end }} \leq V_{\text {eff }}$ which is divided by $V_{\text {eff }}$ so that the stock portion becomes $0 \leq C R C \leq 100 \%$, or:

$$
V_{\text {stock }}=C R C_{t+1} \cdot V_{e f f}
$$

Where $C R C$ is analog with $K_{+1}$. If $V_{\text {stock }}>V_{\text {beg, }}$, then the volume anticipation will increase, or vice versa.

- Quoted from reservoir operation study in Pandanduri earth-filled dam in Lombok river basin, water loss coefficient from evaporation and seepage $0.7-1 \%$ towards $V_{\text {beg }}$ was obtained [38]. In this MEQAA experiment, total water loss $\left(V_{\text {loss }}\right)$ was estimated with $0.7 \%$ coefficient, as:

$$
V_{\text {loss }}=0.7 \% . V_{\text {beg }} \text {. }
$$

For another reservoir, the value of loss coefficient in Equation (9) can be re-adjusted depending on evaporation, storage, and dam construction.

5. Volumetric Equally

- To be quantitative, the equity is analogous to the equality of water allocation portion. The K-factor criterion equals inter-users in upstream (i) and downstream ( $i+1)$ [36], that is:

$$
K_{i}-K_{i+1} \leq \varepsilon .
$$

- C-factor criteria that equal inter-reservoir is:

$$
C_{-} i-C_{i+1} \leq \varepsilon .
$$

- Practically, Equations (5) and (7) are analogs of the supply/demand ratio. For the portion of the current $Q R$ release (K-factor) equals to the portion of anticipation volume $V_{\text {stock }}$ for the coming period (C-factor), then both are equalized with this criterion: (a) if it is surplus then $K=100 \%$ (priority for storage or $C \geq K$ ); (b) if it is limited then $K_{\min } \leq K<100 \%$ (priority for user equal with storage or $K \approx C$ ); and (c) if it is very limited then $K<K_{\min }$ (priority for user or $K>C$ ). In Equation (10) the value of $K$ is obtained from Equation (5).

- In a river system with a suppletion channel/double estuary, the equalization will still review the $\mathrm{K}$-factor and $\mathrm{C}$-factor at each corresponding river reach. The water distribution in this system is controlled by the suppletion regulator towards the target which will be assisted.

6. Water Loss at Reach In the reach of inter-node, there can be a return flow (RF) from the irrigation area that may return to the original/other rivers and lateral loss (LL) due to evaporation/ infiltration. Both are difficult to quantify, and LL is estimated by weighting factor per meter of reach length [10]. In MEQAA, RF and LL are assumed to cancel each other (zero).

7. Intake Capacity Intake capacity of each node $(Q C)$ is assumed to be able to drain $Q R \leq Q D$ maximum or $Q C \geq Q D_{\max }$.

Systems with "n nodes" in "N trajectory" will produce "N.n set equation", for optimizationsimulation from node to node. If the equation is large, then it is impossible to apply an analytical solution, so a simulation is used with iteration $[13,14]$. Simulation is a technique in the model for the study of system behavior by using a computer, according to mathematical descriptions and decision policy so that output is able to be received [24]. To get around inter-time equalization, K-factor and C-factor is used according to $V_{\text {stock }}$ from $C R C_{t+1}$ by using Equation (8). Simulations with progressive 
iteration solutions as Figure 6, with the inter-node concept at each reach (i) in trajectory at a number of river reach $(\mathrm{N})$, are iterated until the $K$ and $C$ are convergent. The simulation will end at the termination status, meaning $K, K$ and $C$, and $C$ are in the tolerance gap ( $\varepsilon \leq 1 \%$ ) [40], and the fulfillment of the constraint criteria with decision variable is nonnegative [30]. Comparison of water allocation solutions utilizes the first-come-first-serve (FCFS) method that is familiar to irrigation practices in Indonesia. The FCFS method prioritizes services in the upstream node, then in downstream [41]. MEQAA will be functionalized to simulate FCFS, by modifying the decision policy according to FCFS characters in Equations (10)-(12).

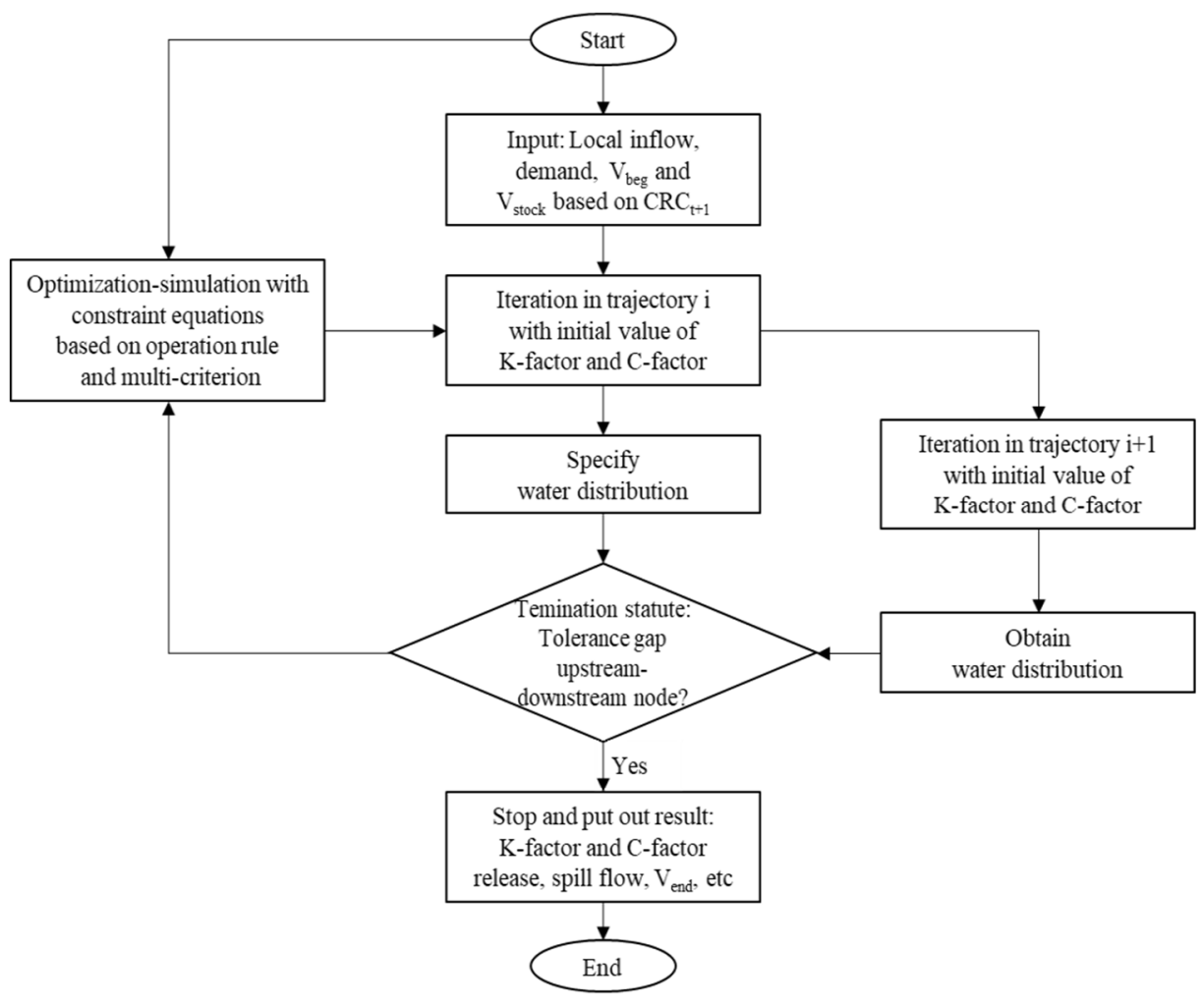

Figure 6. Progressive iteration algorithm in network equation table.

\subsection{Tracking of River Scheme for Network Equation}

The software packages of modeling systems use watershed-based water system configurations, with a Graphical User Interface (GUI) [10,42]. The GUI is a facility of interaction between users and computers, with one of its features being direct manipulation for applications and data functions. Studies have shown that the GUI does not guarantee effective usability, but if it well-designed then it can be more effective than without a GUI [42]. MEQAA is categorized as "semi-GUI" because it uses MS Excel and user intervention.

There is a difference in building a river scheme between software package and MEQAA: if the package software uses GUI facilities to overlay watershed maps, then MEQAA is manual without map overlay. GUI facilities on MEQAA are uses for running process buttons and other instruction buttons, such as nodes tracking in river scheme to be converted to become a network-flow node configuration. In order to be tracked, each node and river reach are coded accordingly Table 2. Furthermore, based on the configuration, MEQAA will formulate a specific model containing the network equation (NE) structure in table form. NE structure uses a dynamic system approach, so it can accommodate system components as a discrete objects collection, to describe the behavior of complex systems [43].

NE structure connects variables between cells in MS Excel according to network-flow node configuration in dynamic systems [10], with the procedure shown in the Figure 7. 
Table 2. The coding guidelines for the network-flow node in river scheme.

\begin{tabular}{|c|c|c|}
\hline Code & Usefulness & Description \\
\hline 100 & Main river & Written above the main river \\
\hline 200,300 , etc. & Tributary & Written above the tributary of the node \\
\hline $1,2,3$, etc. & River junction & $\begin{array}{l}\text { Written on the junction, with formula } \\
\{(\text { tributary code }-100) / 100\}-1\end{array}$ \\
\hline 0 & Main river estuary & Written below the main river estuary \\
\hline B & The initial name for diversion & Written in front of the node/object name \\
\hline $\mathrm{BD}$ & The initial name for reservoir & Written in front of the node/object name \\
\hline BS & $\begin{array}{l}\text { The initial name for extern } \\
\text { suppletion channel }\end{array}$ & Written in front of the node/object name \\
\hline
\end{tabular}

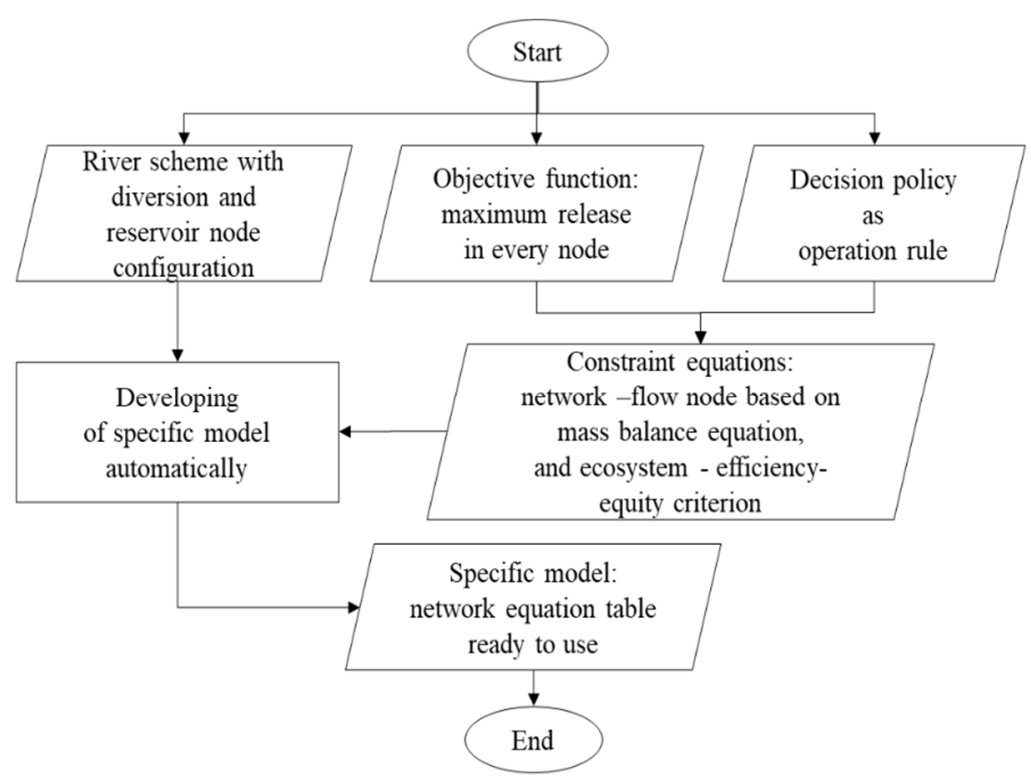

Figure 7. Procedures for the arrangement of the network equation structure.

\subsection{The Criterion of Verification and Validation for the Model}

Referring to [3,44], verification and validation can be arranged according to the modeling concept and the criteria for termination status on Table 3:

1. The syntax code of verification criteria are: (a) configuration of network-flow nodes mapped in domino effect in every river reach; (b) NE structure according to dynamic system and accommodate constraints criteria; and (c) the iteration simulation being able to run to reach the termination status of K-factor, C-factor, and the flow contribution in the suppletion regulator.

2. The criteria of output validation are: (a) maximum QR total; (b) the downstream node having a minimum $Q S$ value which is its $Q E$ value; (c) K-factor, $\mathrm{K}$-factor and C-factor, and C-factor as the portion indicator must reach the maximum-equal value; $(\mathrm{d})$ decision variable is nonnegative (noneg); and e) water balance (WB) control is null.

Table 3. Criteria for termination status.

\begin{tabular}{clll}
\hline \multicolumn{1}{c}{ Item } & Key Indicator & \multicolumn{1}{c}{ Releated Components } & \multicolumn{1}{c}{ Function } \\
\hline K_draft & - & $Q R, Q D$ & K iteration, from $100 \%$ to 0 with step $\leq 1 \%$ \\
\hline Noneg & 1 & $\begin{array}{l}Q \\
Q E \geq 0, Q R \geq 0, Q S \geq Q E,\end{array}$ & $\begin{array}{l}\text { Criteria indicator for decision variables } \\
\text { without containing negative values. }\end{array}$ \\
\hline Stor_key & 1 & $\begin{array}{l}\mathrm{DR} \text { key } \text { include } V_{\text {cal }}, Q A, Q D, \\
Q R, Q E \text { towards } \mathrm{KC}_{-\mathrm{key}} .\end{array}$ & Criteria indicator for decision variables. \\
\hline
\end{tabular}


Table 3. Cont.

\begin{tabular}{llll}
\hline \multicolumn{1}{c}{ Item } & Key Indicator & \multicolumn{1}{c}{ Releated Components } & \multicolumn{1}{c}{ Function } \\
\hline C_draft & - & $V_{\text {end }}, V_{\text {stock }}, V_{\text {eff }}$ & C iteration, from C_max to 0 with step $\leq 1 \%$. \\
\hline WB & 0 & $V_{\text {beg }}, V_{\text {loss }}, V_{\text {end }}, Q A, Q R, Q S$ & $\begin{array}{l}\text { Criteria indicator for water balance } \\
\text { (input-output on mass balance equation) }\end{array}$ \\
\hline C_max & - & $V_{\text {cal }}, V_{\text {stock }}, V_{\text {eff }}$ & $\begin{array}{l}\text { Maximum value of C iteration. } \\
\left(0 \leq C_{\text {_max }} \geq 100 \%\right)\end{array}$ \\
\hline $\mathrm{CK}_{-}$key & 1 & $Q S, Q E, K, C, V_{\text {end }}, V_{\text {eff }}$ & Criteria indicator for decision variables. \\
\hline $\mathrm{K}_{-}$key & 1 & $Q R, Q D, K$ & Criteria indicator for decision variables. \\
\hline
\end{tabular}

\section{Experimental}

\subsection{Operation Procedure}

In Figure 8 on the left side there are (a) a black box containing buttons that can be selected according to their functions, (b) DAR meter (demand/available ratio) as a global water balance indicator, as surplus $(<100 \%)$, balance $(100 \%)$ or deficit $(>100 \%)$, (c) RDR meter (release/demand ratio) as an indicator of global water allocation reliability $(0-100 \%)$, and (d) iteration box (located below RDR meter) as an indicator of the total of iterations until it reaches the termination status in the tolerance gap. The movement of DAR meter indicator is according to input data, while RDR meter and number of iterations are according to the result of simulation optimization at each data input.

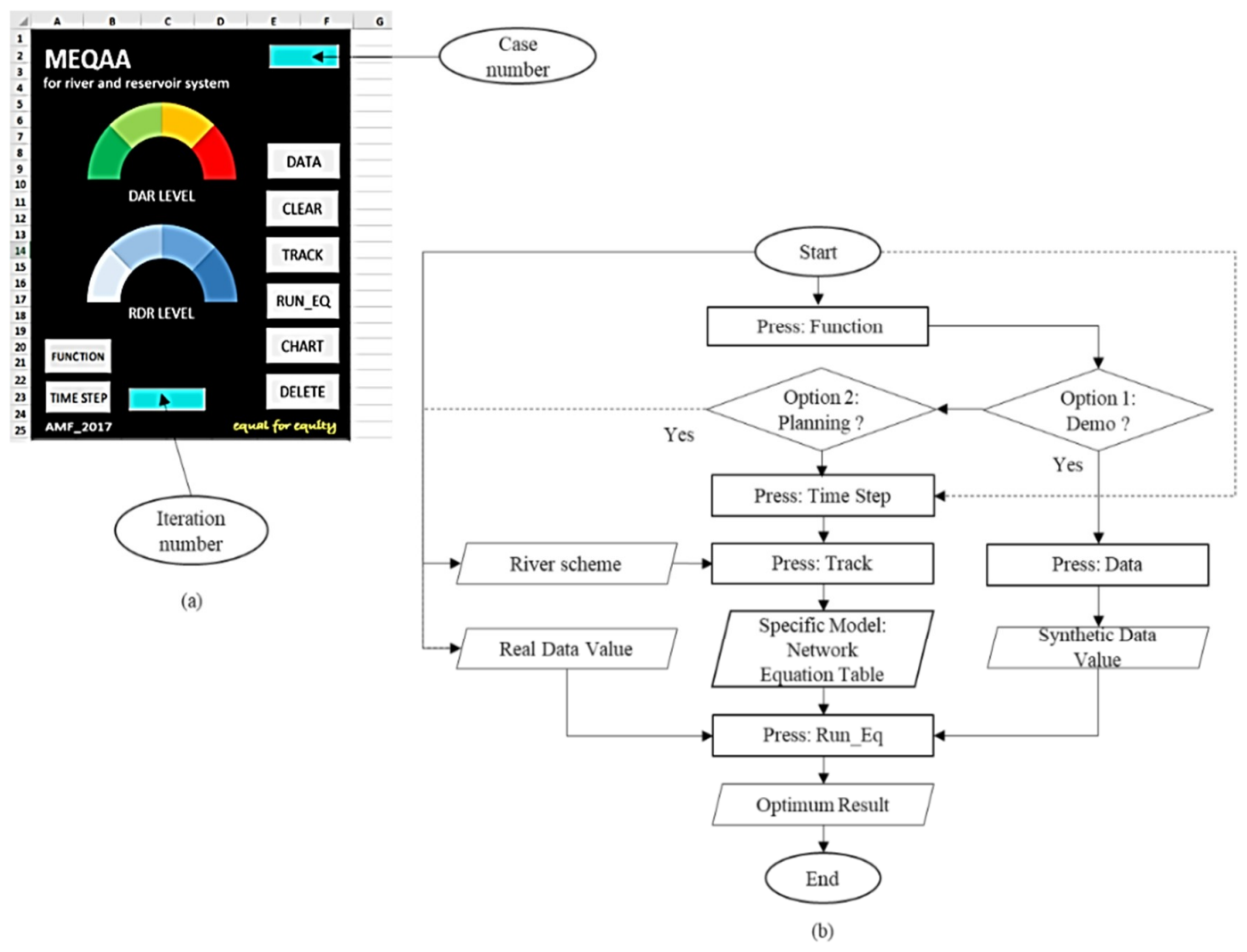

Figure 8. (a) MEQAA user interface facility with instruction buttons; (b) Standard operating procedures of MEQAA.

The MEQAA operating procedure that is shown in Figure 8 is (a) create or copy the schemas available in the spreadsheet manually according to MS Excel procedures, and (b) choosing the process 
buttons, include: (i) FUNCTION for selecting DEMO (with synthetic data) or PLANNING (with real data), (ii) TRACK to determine the network-flow node configuration in the river scheme and to get the NE table, (iii) RUN_EQ for optimization-simulation, (iv) CLEAR for removing the NE table, (v) DELETE for deleting the entire format, (vi) DATA for inputting data in each case period-this button is only active when the DEMO button is selected, (vii) CHART for showing output information graphically, and (viii) TIME STEP for options for time step in each case (period 1, 5, 10, 15, and 30 each day). This experiment uses time step for 10 each day. Meanwhile, software packages of other modeling systems also have time step options such as hourly, daily, half-monthly, and monthly [10,16].

If a K-factor is less than $\mathrm{K}_{\mathrm{min}}$, then MEQAA will display the on-off rotation option information. If the user agrees to on-off rotation, it is necessary to specify nodes that are not given water. Choosing a closed gate at a certain node in a river scheme is done using the "Format Painter" feature in MS Excel based on the standard color of "closed" (gray). The choice of the target location for water distributed is according to priority scale, based on the critical period of the plant. Then, RUN_EQ is selected again to get a larger K-factor.

\subsection{Data Input}

Experiments using a synthetic river scheme (Figure 9) combine 5 types of schemes in Figure 2, with diversion, multi-reservoir and suppletion regulator. The schemes are system-dependent because there is a supply channel of river reach (RR) 500 in the XYZ River flows to RR 600 in another river. In the scheme, the input has been coded according to the guidelines in Table 2 . In the scheme there are 6 river reaches (RR 100-600), 5 junctions, 1 suppletion channel, 1 main estuary (0), 1 s estuary, 7 diversions (B6, B8, B4, B9, B15, B12, and B13), 6 reservoirs (BD1, BD5, BD7, BD2, BD10, and BD14) and 2 suppletion regulators (BS 3 and BS 11). All water users are irrigations.

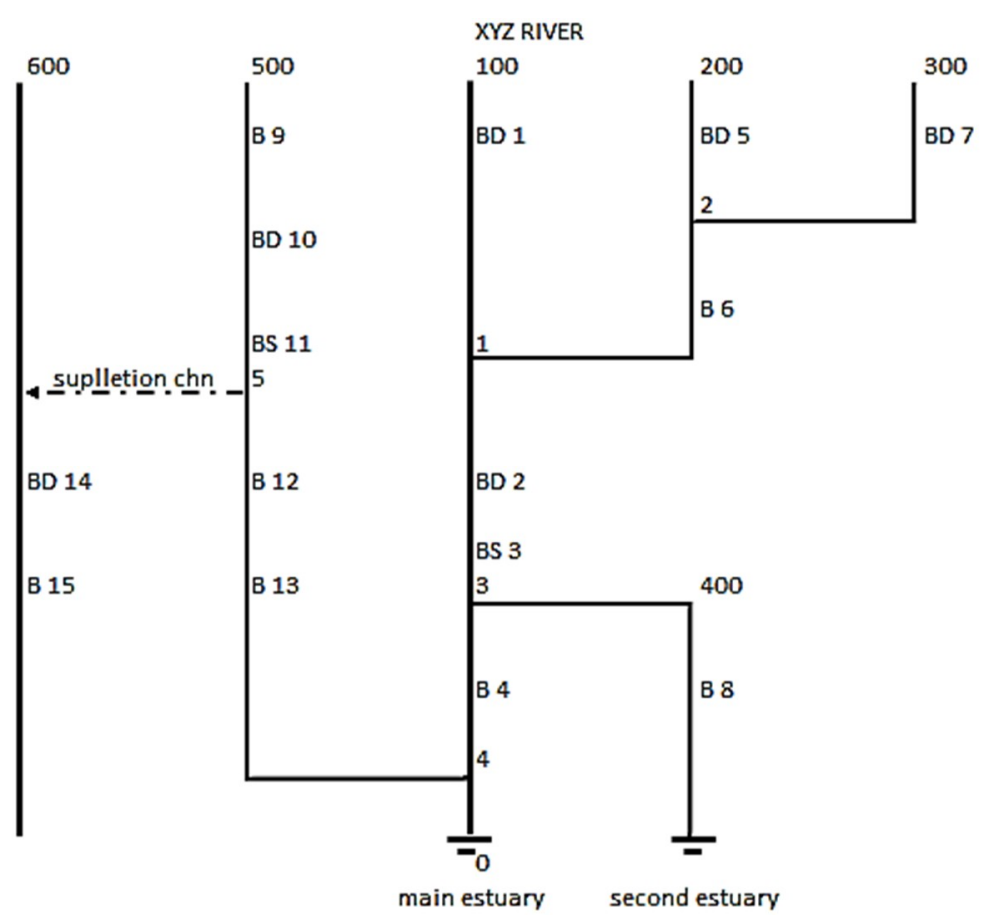

Figure 9. Synthetic river scheme.

The data value is random within ranges: (a) QL 0-2.094 L/s; (b) QD 0-6.381 L/s); (c) $V_{\text {eff }}$ $11,000,000-26,000,000 \mathrm{~m}^{3}$; (d) $V_{\text {beg }} 9,720,000-21,320,000 \mathrm{~m}^{3}$; and (e) $V_{\text {stock }} 4,420,000-20,000,000$, based on the characteristics of the Lombok river basin. The value of $V_{\text {stock }}$ is determined from the CRC of each reservoir; BD1, BD5, BD7, BD2, BD10, and BD14 are respectively 77\%, 59\%, 63\%, 43\%, 40\%, and $67 \%$ towards $V_{\text {eff. }}$. The CRC portion is a random value contained in the MEQAA syntax code and is not 
shown in the NE table. In this case, these generally occur: (a) increased water demand in operation in future periods $\left(V_{\text {stock }}>V_{\text {beg }}\right)$ in BD7 and BD2, whereas other reservoirs are the opposite $\left(V_{\text {stock }}<V_{\text {beg }}\right)$, and (b) global water balance is surplus-fluctuating with 53\% of DAR. By using the same data value, the output of methods with and without equalization will be comprised.

\section{Results and Discussion}

\subsection{Network Equation Table}

The NE structure connects Equation (1) to (12) according to the network-flow node configuration as exemplified by some NE tables in Figure 10, with the explanation of notation in Figure 11. For the scheme in, MEQAA forms a trajectory according to the sequence of hydraulic in every headwork node printed on the $U$ column in each river reach on the AU column. AT column informs the location of the node located at the most upstream in each river reach. As long as no changes are made to the nodes in the system, each river scheme will have only one specific NE table.

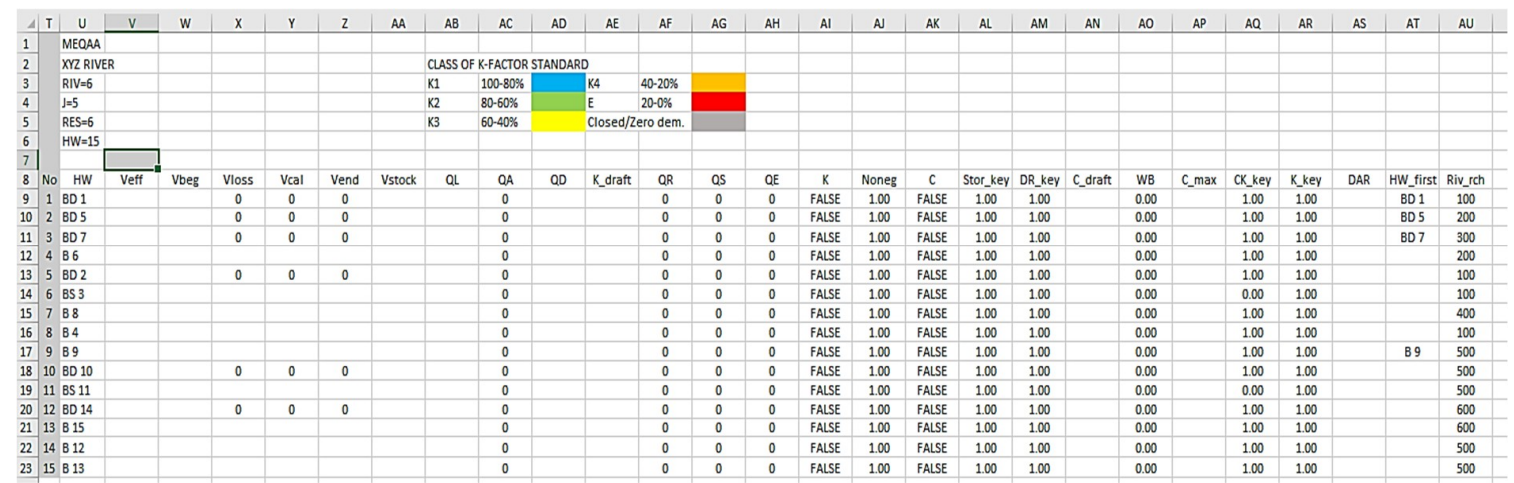

Figure 10. Some network equation tables for optimization-simulation.

\begin{tabular}{|c|c|c|c|c|c|c|c|c|c|c|c|c|c|c|c|c|}
\hline \multirow[b]{2}{*}{ No } & \multirow[b]{2}{*}{ HW } & $\begin{array}{l}\text { Case_1 } \\
\text { It_4193801 }\end{array}$ & & \multicolumn{3}{|c|}{ Sum_QL_12222 I/s } & \multicolumn{3}{|c|}{$\begin{array}{l}\text { Sum_Vbeg_69125000 m3 } \\
\text { Sum_Vend_51624146 m3 }\end{array}$} & \multicolumn{2}{|c|}{$\begin{array}{l}\text { Sum_QD_48833 I/s } \\
\text { Sum_QR_31369 I/s }\end{array}$} & \multicolumn{5}{|c|}{$\begin{array}{l}\text { DAR_53\% } \\
\text { RDR_64\% }\end{array}$} \\
\hline & & Veff & Vbeg & Vloss & Vend & Vstock & $\mathrm{QL}$ & QA & $Q D$ & QR & QS & QE & $\mathrm{K}$ & Class_K & C & Qsup* \\
\hline 1 & BD 1 & 26000000 & 21320000 & 42640 & 16200000 & 20000000 & 2094 & 2094 & 5381 & 4359 & 3612 & 107 & $81 \%$ & $\mathrm{~K} 1$ & $81 \%$ & \\
\hline 2 & BD 5 & 17000000 & 11220000 & 22440 & 8000000 & 10000000 & 1314 & 1314 & 4933 & 3946 & 1068 & 67 & $80 \%$ & K1 & $80 \%$ & \\
\hline 3 & BD 7 & 24000000 & 14880000 & 29760 & 12000000 & 15000000 & 1943 & 1943 & 2113 & 1690 & 3551 & 99 & $80 \%$ & K1 & $80 \%$ & \\
\hline 4 & B 6 & & & & & & 281 & 4901 & 5874 & 4656 & 245 & 245 & $80 \%$ & $\mathrm{~K} 1$ & & \\
\hline 5 & $\mathrm{BD} 2$ & 26000000 & 10860000 & 21720 & 9055800 & 11180000 & 0 & 3857 & 1911 & 1567 & 4353 & 194 & $82 \%$ & $\mathrm{~K} 1$ & $81 \%$ & \\
\hline 6 & BS 3 & & & & & & 0 & 4353 & 0 & 0 & 218 & 218 & & & & 4135 \\
\hline 7 & B 8 & & & & & & 1329 & 5464 & 6381 & 5191 & 273 & 273 & $81 \%$ & K1 & & \\
\hline 8 & B 4 & & & & & & 1302 & 1520 & 1002 & 1002 & 518 & 76 & $100 \%$ & K1 & & \\
\hline 9 & B 9 & & & & & & 2020 & 2020 & 5076 & 1919 & 101 & 101 & $38 \%$ & K4 & & \\
\hline 10 & BD 10 & 11000000 & 9720000 & 19440 & 1906346 & 4420000 & 1500 & 1601 & 0 & 0 & 10622 & 81 & & & $43 \%$ & \\
\hline 11 & BS 11 & & & & & & 0 & 10622 & 0 & 0 & 3395 & 531 & & & & 7228 \\
\hline 12 & BD 14 & 15000000 & 1125000 & 2250 & 4462000 & 10000000 & 0 & 7228 & 5219 & 2296 & 1066 & 362 & $44 \%$ & K3 & $45 \%$ & \\
\hline 13 & B 15 & & & & & & 0 & 1066 & 2358 & 1013 & 53 & 53 & $44 \%$ & K3 & & \\
\hline 14 & B 12 & & & & & & 0 & 3395 & 3981 & 1752 & 1643 & 170 & $44 \%$ & K3 & & \\
\hline 15 & B 13 & & & & & & 439 & 2082 & 4604 & 1978 & 104 & 104 & $44 \%$ & K3 & & \\
\hline
\end{tabular}

Figure 11. Computation output with equalization method.

On the tracking scheme (Figure 9), the total trajectory obtained are river reach (RIV) $=6$, junctions $(J)=5$, reservoirs $($ RES $)=6$, and headwork node $(H W)=15$ with information presented in the top left corner of the NE table. The format and load on the NE table are always dynamic, following the network-flow node configuration and type of node. The NE table format in the configuration with diversion will be simpler and shorter since there is no storage function. If there is a reservoir in the system, the NE table format will be wider, because there is a storage function. Table 4 will be at maximum if the system contains a complete mix of diversions, reservoirs, and suppletion channel/double estuary as shown in Figure 9. The illustration in Figure 10 is an example of NE table in maximum capacity, due to the case with complex river scheme configuration. 
Table 4. Notation in NE table.

\begin{tabular}{|c|c|c|c|c|}
\hline No & Notation & Acronym & Description & Equation \\
\hline 1 & No & Node number & Output from tracking & - \\
\hline 2 & HW & Headwork configuration & Output from tracking & - \\
\hline 3 & $V_{e f f}$ & Effective volume & Input data & - \\
\hline 4 & $V_{\text {beg }}$ & Beginning volume & Input data & - \\
\hline 5 & $V_{\text {loss }}$ & Losses volume & Calculated & (9) \\
\hline 6 & $V_{\text {end }}$ & End volume & $\begin{array}{l}\text { Calculated from } V_{c a l} \\
\text { (boundary operation) }\end{array}$ & (6) \\
\hline 7 & $V_{\text {stock }}$ & $\begin{array}{l}\text { Stock volume anticipation } \\
\text { for next operation period }\end{array}$ & Calculated & (8) \\
\hline 8 & $Q L$ & Local inflow & Input data & - \\
\hline 9 & $Q A$ & Water available (total inflow) & Calculated & (3) \\
\hline 10 & $Q D$ & Water demand & Input data & - \\
\hline 11 & $\tilde{Q} R$ & Intake release & Calculated & Connected \\
\hline 12 & $\tilde{Q S}$ & Spill flow/contribution & Calculated & Connected \\
\hline 13 & $\widetilde{Q} E$ & Ecosystem water need & Calculated & (4) \\
\hline 14 & $\widetilde{\mathrm{K}}_{\text {draft}}, \mathrm{K}$ & $\mathrm{K}$ iteration and optimum & Calculated & (5), (10), (12) \\
\hline 15 & Class_K & Class of $\mathrm{K}$ & From Table 1 & - \\
\hline 16 & $\mathrm{C}_{\text {_draft}}, \mathrm{C}$ & C iteration and optimum & Calculated & (7), (11), (12) \\
\hline 17 & $\begin{array}{l}\text { Stor_key, } \\
\text { DR_key, } \\
\text { CK_key, K_key }\end{array}$ & $\begin{array}{l}\text { Termination status indicator } \\
\text { at iteration process }\end{array}$ & Calculated & Connected \\
\hline 18 & Noneg, WB & Control indicator at optimization criterion & Calculated & Connected \\
\hline
\end{tabular}

In Figure 10 there are empty cells, which (a) in columns V, W, AA, $Q L$, and $Q D$ will be filled by input data such as Veff and others, (b) in column AW will be filled with K_draft iteration $(100 \%-0)$ with a certain step_K (1\%), (c) in column AN will be filled with C_draft iteration $(\geq 100 \%-0)$ based on C_max in AP column, with step_C synchronized with step_K, and (d) in column US will be filled with local DAR values according to $Q D$ and $Q L$ input data in each node. C_max is a storage portion potential calculated from Equation (7). As in the columns with cells that have been filled/printed, a formula is automatically loaded describing objective function and constraint equations, which (a) in column X, cells X9 $=$ W9 $\times 0.002$ are Equation (9) with X9 $=V_{\text {loss }}$ and W9 $=V_{\text {beg }}$ and (b) in column K, cells $\mathrm{K} 9$ = AF9/AD9 are Equation (5) with $\mathrm{K} 9=\mathrm{K}$-factor optimum, AF9 = optimum release, and AD9 $=$ demand. These values will remain after the simulation reaches the termination state. Meanwhile, in cells with numbers of 1 or 0 , the columns $\mathrm{X}, \mathrm{Y}, \mathrm{Z}, \mathrm{AC}, \mathrm{AF}$ AG, AH, AI, and AK will automatically change according to the iteration simulation until it reaches the termination state. If all cells in the $\mathrm{AJ}, \mathrm{AL}, \mathrm{AM}, \mathrm{AO}, \mathrm{AQ}$, and $\mathrm{AR}$ columns contain constants with code 1 or 0 values, according to the constraint equations criteria, then the termination status has been reached.

\subsection{Output with Equalization}

Verification and validation based on criteria on point 2.7 are done to fit the modeling purpose. It is done gradually and repeatedly, starting from simple river scheme to complex river scheme along with the data value of each node. MEQAA forms the NE table automatically and quickly; overall it is less than $10 \mathrm{~s}$ after clicking the "TRACK" button. The duration of the calculation depends on the type of node, the complexity of the river scheme, and the data variability (in this case it takes $2174 \mathrm{~s}$ to complete). Verification of syntax code found that: (a) network-flow node configuration matches trajectory in RR 100RR 600, with a domino effect at 15 nodes; (b) The table contains the NE structure according to Equation (1) to (11) which link up inter-variables and internodes; and (c) iteration always leads to the convergence of $\mathrm{K}, \mathrm{C}$, and the contribution of the flow in the suppletion regulator to achieve the termination state. Output validation at each node generates: (a) maximum release; (b) the ecosystem water need met from spill flow; (c) as long as water can be shared, equal value on $\mathrm{K}, \mathrm{K}$ and $\mathrm{C}$, and $\mathrm{C}$ including contaminant contribution in supplement; (d) non-negative variable; and (e) null 
water balance control. All the output of this method is to satisfy the sustainability-efficiency-equity criteria as the main constraint of MEQAA. All decision variables fit Equations (1) to (11).

In the equalization method of water allocation, available water is released proportionally according to demand, by considering the downstream water requirements and anticipated volumes for the upcoming operating period. The MEQAA output illustrates water distribution in Figure 11, based on data input at point 3.2. In general, the total remaining storage is $51,624,146 \mathrm{~m}^{3}$, the total release is $31,369 \mathrm{~L} / \mathrm{s}$, total supply is $11,362 \mathrm{~L} / \mathrm{s}$, RDR average is $64 \%$, and ecosystem water need is filled from spill flow at each node.

Since the equalization method of water allocation is emphasizing the water distribution, the $K$ has been equal at $44-100 \%(K 1, K 2, K 3$, and K4). Downstream $K$ equals upstream $K$, there is no emergency (E), and release is more than demand. The achievement of the $C$ has been equal at $44-81 \%$; it means each reservoir prepares $V_{\text {stock }}$ for future operational needs.

In RR 100, 200, 300, and 400, regarding BD1, BD5, BD7, and BD2, these are multi-reservoirs (cascade-parallel type) with $V_{\text {beg }}$ less than $V_{\text {eff. }}$ BD5 and BD7 have to share the water to B6, so the $K$ is equal at $80-81 \%$ (from Table 1 obtained $\mathrm{K} 1$ ) and $C$ is equal at $80-81 \%$. The achievement of $C$ is less than $100 \%$ because local inflow and $V_{\text {beg }}$ are limited so it is difficult to meet the load factor. Contribution from $\mathrm{BD} 1$ to $\mathrm{BD} 2$ with $\mathrm{K}$ is $81-82 \%$ and $C$ is $81 \%$, proceeding to the double estuary through suppletion regulator of BS3 at $4135 \mathrm{~L} / \mathrm{s}$, so B8 reaches $81 \%$ of its $\mathrm{K}$. B4 does not need supply from BS3, because reach BS3-B4 have local inflow in the amount of $1302 \mathrm{~L} / \mathrm{s}$, so the water availability $(1520 \mathrm{~L} / \mathrm{s})$ is greater than demand $(1002 \mathrm{~L} / \mathrm{s})$. As a result of a surplus in $\mathrm{B} 4$, the $\mathrm{K}$ in $\mathrm{B} 4$ reaches $100 \%$ and spill flow is $518 \mathrm{~L} / \mathrm{s}$, which is greater than the ecosystem water need $(76 \mathrm{~L} / \mathrm{s})$. While spill flow in $\mathrm{B} 8$ for ecosystem water need is $273 \mathrm{~L} / \mathrm{s}$, it complies with the criteria of minimizing spill flow.

RR 500 and 600 have BD10 as reservoir regulator (without demand) and BD 14. Both are a cascade, but among them, there is a suppletion regulator BS11 as a contribution towards RR 600. RR 500 ends at downstream B4, while RR 600 is the dry river with the most downstream node in B15. B9 has 38\% of $\mathrm{K}$ since the local inflow is only $2020 \mathrm{~L} / \mathrm{s}$ which must be shared with $5076 \mathrm{~L} / \mathrm{s}$ of demand and $101 \mathrm{~L} / \mathrm{s}$ of ecosystem water need. Meanwhile, BD10 which has no demand is in the downstream of B9, so $10,622 \mathrm{~L} / \mathrm{s}$ of spill flow is used to assist downstream needs and $7288 \mathrm{~L} / \mathrm{s}$ of supply to RR 600 through BS11. Because the water is limited in RR, the $\mathrm{K}$ achievement is $44 \%$ (from Table 1: water distribution in irrigation area by using rotation- $2 /$ medium $/ \mathrm{K} 3$ ) and $C$ achievement is $43-45 \%$; both of them are equal. Spill flow at the downstream nodes B13 and B15 are equal to their own ecosystem water need, according to the efficiency criterion

RR 100-400 and RR 500-600 achieved $K$ and C with the same value, which was $80-81 \%$ for RR 100-400 and 43-45\% for RR 500-600. In this case, in each reservoir, $V_{\text {stock }}$ for the next period is only partially fulfilled from the current $V_{\text {end }}$ or $V_{\text {end }}<V_{\text {stock }}$, so $C<100 \%$; however, the current supply/demand is the same as the next period $(K \approx C)$. It can be said that supply/demand inter-time are equal. In conditions of limited water availability $(K<100 \%)$ MEQAA can be designed to enhance the current release but it may endanger the next operation; conversely, decreasing the current release will give a benefit to the next period of operation. Both of these conditions do not pay attention to the sustainability of the operation, including the storage portion inter-reservoir, so the $K$ decision policy being equal to $C$ is reasonable. If the condition is surplus $(K=100 \%)$, then the reservoir will store water limited to $V_{\text {eff }}$ in order to reach $V_{\text {end }} \geq V_{\text {stock }}$ or $C \geq K$. Meanwhile, there is no drought condition $(K<$ $K_{\min }$ or emergency) in this case, so MEQAA does not show the information option of on-off rotation. On-off rotation is recommended during a drought in real-time operation.

In the iteration of $K$ and $C$, it has a tolerance gap of error $\varepsilon=1 \%$, so it can be categorized as the smallest error for the solution of water allocation. The simulation based on data input at point 3.2 takes 4,193,801 iterations. The number of iterations depends on the complexity of the system or trajectory, the characteristics of the data value or the water balance at each reach, and the iteration step. An increasingly complex system requires a long duration of iteration, including when deficit in reach occurs. 


\subsection{Output without Equalization}

Calculations are performed using NE table on equalization method, with a decision policy that does not follow objective function in Equation (2) and sustainability-efficiency-equity criteria on constraint equations. Decision policy includes: (a) water available in the upstream node will be used as a release as much as demand or greater and (b) the downstream needs will be given after the fulfillment of upstream needs [20]. Another policy is to prioritize the use of water in the reservoir for the present rather than operations in a later period. MEQAA is modified in such a way so that it can emulate the behavior of FCFS. Based on the decision policy and the input data in point 3.2 the results are $57,061,200 \mathrm{~m}^{3}$ of total remaining storage, $25,790 \mathrm{~L} / \mathrm{s}$ of total release, $7270 \mathrm{~L} / \mathrm{s}$ of total suppletion, mean of RDR is 53\%, and ecosystem water need is not fulfilled at B6, BS3, B8, B9, B15, B12, and B13. The calculation results are presented in Figures 12 and 13b.

\begin{tabular}{|c|c|c|c|c|c|c|c|c|c|c|c|c|c|c|c|c|}
\hline & & $\begin{array}{l}\text { Case_1 } \\
\text { It_54448 }\end{array}$ & & um_QL & $\begin{array}{l}2222 \mathrm{l} / \mathrm{s} \\
119000000\end{array}$ & & $\begin{array}{l}\text { Sum_vb } \\
\text { Sum_Ve }\end{array}$ & 591250 & & $\begin{array}{l}\text { Sum_QD } \\
\text { Sum_QR }\end{array}$ & $\begin{array}{l}333 \mathrm{l} / \mathrm{s} \\
90 \mathrm{l} / \mathrm{s}\end{array}$ & & & $\begin{array}{l}\text { DAR_53\% } \\
\text { RDR_53\% }\end{array}$ & & \\
\hline No & $\mathrm{HW}$ & Veff & Vbeg & Vloss & Vend & Vstock & $\mathrm{QL}$ & QA & $Q D$ & QR & QS & QE & $\mathrm{K}$ & Class_K & C & Qsup* \\
\hline 1 & BD 1 & 26000000 & 21320000 & 42640 & 18200000 & 20000000 & 2094 & 2094 & 5381 & 5381 & 275 & 107 & $100 \%$ & K1 & $91 \%$ & \\
\hline 2 & BD 5 & 17000000 & 11220000 & 22440 & 8000000 & 10000000 & 1314 & 1314 & 4933 & 4933 & 82 & 67 & $100 \%$ & $\mathrm{~K} 1$ & $80 \%$ & \\
\hline 3 & BD 7 & 24000000 & 14880000 & 29760 & 14550000 & 15000000 & 1943 & 1943 & 2113 & 2113 & 178 & 99 & $100 \%$ & K1 & $97 \%$ & \\
\hline 4 & B 6 & & & & & & 281 & 541 & 5874 & 541 & 0 & 27 & $9 \%$ & $E$ & & \\
\hline 5 & BD 2 & 26000000 & 10860000 & 21720 & 9391200 & 11180000 & 0 & 275 & 1911 & 1911 & 39 & 15 & $100 \%$ & K1 & $84 \%$ & \\
\hline 6 & BS 3 & & & & & & 0 & 39 & 0 & 0 & 0 & 2 & & & & 39 \\
\hline 7 & B 8 & & & & & & 1329 & 1368 & 6381 & 1368 & 0 & 68 & $21 \%$ & K4 & & \\
\hline 8 & B4 & & & & & & 1302 & 1302 & 1002 & 1067 & 235 & 65 & $107 \%$ & $\mathrm{~K} 1$ & & \\
\hline 9 & B 9 & & & & & & 2020 & 2020 & 5076 & 2020 & 0 & 101 & $40 \%$ & K3 & & \\
\hline 10 & BD 10 & 11000000 & 9720000 & 19440 & 4420000 & 4420000 & 1500 & 1500 & 0 & 0 & 7612 & 76 & & & $100 \%$ & \\
\hline 11 & BS 11 & & & & & & 0 & 7612 & 0 & 0 & 381 & 381 & & & & 7231 \\
\hline 12 & BD 14 & 15000000 & 1125000 & 2250 & 2500000 & 10000000 & 0 & 7231 & 5219 & 5219 & 418 & 362 & $100 \%$ & K1 & $25 \%$ & \\
\hline 13 & B 15 & & & & & & 0 & 418 & 2358 & 418 & 0 & 21 & $18 \%$ & $E$ & & \\
\hline 14 & B 12 & & & & & & 0 & 381 & 3981 & 381 & 0 & 19 & $10 \%$ & $E$ & & \\
\hline 15 & B 13 & & & & & & 439 & 439 & 4604 & 439 & 0 & 22 & $10 \%$ & $E$ & & \\
\hline
\end{tabular}

Figure 12. Computation output with FCFS method.

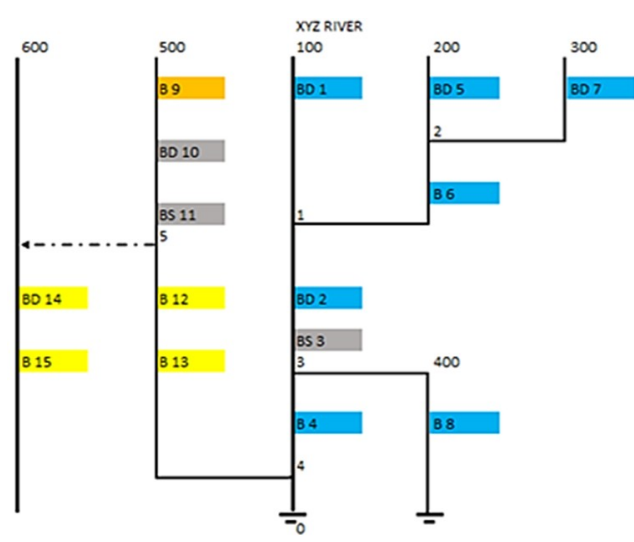

(a)

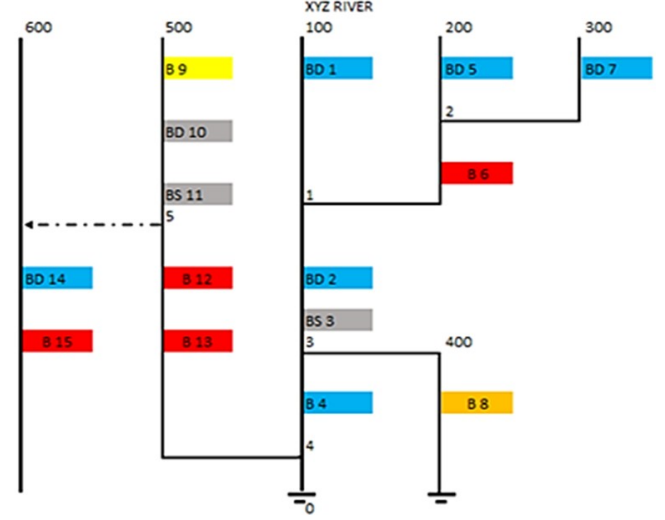

(b)

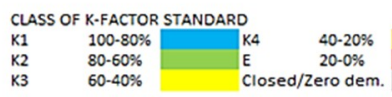

(c)

Figure 13. Class of K-factor comparison in the scheme. (a) With equalization; (b) Without equalization (FCFS method); (c) Class of K-factor standard.

The FCFS method results in an uneven distribution of Ks between 9-107\% (K1, K3, K4, and E). $\mathrm{K}$ in downstream nodes that contain much water will be difficult to be optimized, and even emergency (E) happens as in B6. Inefficiency $(\mathrm{K}>100 \%)$ of water withdrawal occurs in B4 with $K$ reaching $107 \%$, because the release is greater than demand. In addition, the uneven distribution of $C$ between $25 \%$ and $100 \%$, because in each reservoir competes to fill the storage than the water distribution to downstream. Water available is prioritized for current operational needs rather than for a later period. From Figure 3 it appears that this method which is selfish user-oriented does not anticipate volume for 
future operations across all reservoirs $(C<K)$. Application of FCFS method will decrease available volume in the reservoir before the end of operation cycle according to plan.

\subsection{Output Comparison}

From the output of the two water allocation methods, the class of K-factor comparisons in the river scheme is presented in Figure 13 and K-factor and C-factor are presented in graph form in Figure 14. Figure 14 is a bar chart that displays node-based output information, as a correlation between K-factor and C-factor at each node. From the chart, there are significant differences between $\mathrm{K}$-factor and $\mathrm{C}$-factor in each node due to the application of the equalization and first-come-first-serve (FCFS) methods. In the Prop method, in each reservoir, there are K-factor and C-factor that reach equality, as well as K-factor internodes which reach equality. In contrast, FCFS experiences unequal conditions that become disadvantageous to the water allocation in interspace and time, including ecosystem water need.

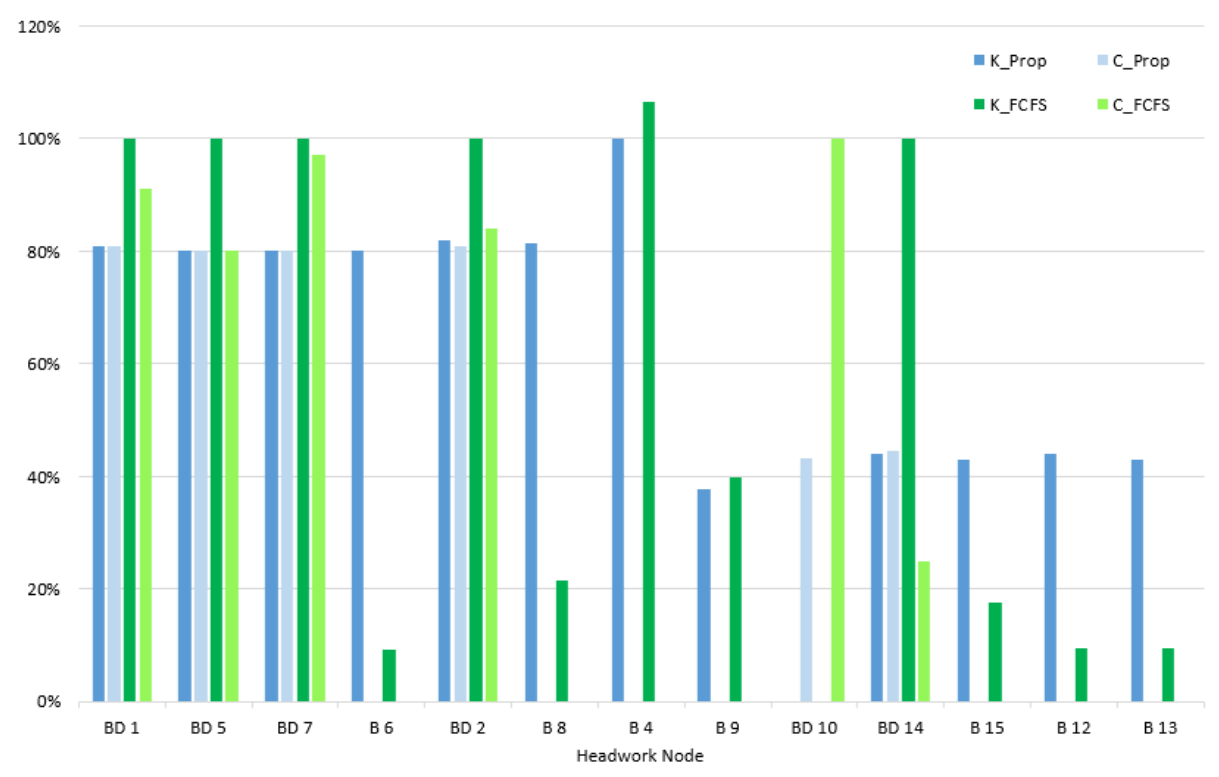

Figure 14. K-factor and C-factor comparison.

The FCFS method generates more release than demand, and thus it is inefficient, as it does not consider downstream needs including the ecosystem water need, and it does not anticipate operations in upcoming periods in the reservoir. The practice of water allocation with this method will be prone to conflict because it is self- oriented. If it is unequal, then there will be protests by downstream users, because the threat of drought. All output of FCFS method does not satisfy the sustainability-efficiency-equity criteria as the main constraint of MEQAA and does not according with the criteria for termination status. Additional water to downstream can be provided through difficult negotiations with results determined by upstream users. Otherwise, conducive and productive conditions will occur when applying water allocation by using the equalization method.

\section{Conclusions}

From the results and discussion, it can be concluded that:

1. MEQAA can track network-flow node configuration in independent river systems to create a network equation structure as the main equation of computational model, with input single data and output based on operation rule and the sustainability-efficiency-equity criteria. 
2. Number of iterations in the simulation of water allocation depends on the iteration step, network-flow node configuration, local inflow, water demand, and the beginning volume of the reservoir.

3. Based on experiments using complex synthetic river schemes and containing many diversions and multi-reservoirs, suppletion channels and double estuaries that are described from the complexity of the system in Lombok river basin, MEQAA as a dynamic system-based deterministic model can work according to its function and the result is in accordance with the constraint.

4. The output of MEQAA satisfied the sustainability-efficiency-equity criteria, being that spill flow/contribution flow is adequate with ecosystem quota on downstream nodes; the release is efficient since it does not exceed demand with the K-factor minimum of $40 \%$, and water allocation portion in internode is equal.

5. The practice of water allocation by equalization method according to the sustainability-efficiencyequity criteria will simultaneously integrate inter-user benefit and ecosystem quota, release, demand and water availability, upstream-downstream, and wet-dry river, storage portion in multi-reservoirs for current and future periods. In contrast, the first-come-first-serve method will cause a conflict, because of unsustainability-inefficiency-inequity.

MEQAA is potentially developed for (a) water allocation solution in the interdependent system with the multi-river interconnection, and (b) water allocation plan based on time series data in reservoir system, in order to make $\mathrm{K}$-factor and C-factor equal or decreasing gradually from period to period. Spill flow as MEQAA output requires travel time model, for water delivery calculation of travel time in real-time operation.

Author Contributions: Conceptualization, A.M.F., P.T.J., E.S. and V.D.; Formal analysis, A.M.F.; Methodology, A.M.F. and V.D.; Software, A.M.F.; Supervision, P.T.J., E.S. and V.D.; Writing—original draft, A.M.F.; Writingreview \& editing, E.S. and V.D.

Funding: This research received no external funding.

Acknowledgments: Thanks are due to the individual consultant as a youth professional engineer in Water Allocation Unit-Balai Wilayah Sungai Nusa Tenggara I, Lombok river basin.

Conflicts of Interest: The authors declare no conflicts of interest.

\section{References}

1. Fulazzaky, M.A. Review-Challenges of integrated water resources management in Indonesia. Water 2014, 6, 2000-2020. [CrossRef]

2. Strauß, S. Water conflicts among different user groups in South Bali, Indonesia. Hum. Ecol. 2011, 39, 69-79. [CrossRef]

3. Eriyatno. Ilmu Sistem-Meningkatkan Mutu dan Efektivitas Manajemen; Guna Widya: Surabaya, Indonesia, 2012.

4. Roozbahani, R.; Abbasi, B.; Schreider, S.; Ardakani, A. A multi-objective approach for transboundary river water allocation. Water Resour. Manag. 2014, 28, 5447-5463. [CrossRef]

5. Peraturan Pemerintah Republik Indonesia No. 121 Tahun 2015 tentang Pengusahaan Sumber Daya Air. Available online: http:/ / ditjenpp.kemenkumham.go.id/arsip/ln/2015/pp121-2015bt.pdf (accessed on 18 July 2018).

6. UN Water. The United Nations World Water Development Report 2015 "Water for a Sustainable World"; UNESCO: Paris, France, 2015.

7. Roozbahani, R.; Abbasi, B.; Schreider, S. Optimal allocation of water to competing stakeholders in a shared watershed. Ann. Oper. Res. 2015, 229, 657-676. [CrossRef]

8. Perera, B.J.C.; James, B.; Kularathna, M.D.U. Computer software tool REALM for sustainable water allocation and management. J. Environ. Manag. 2005, 77, 291-300. [CrossRef] [PubMed]

9. Sulis, A.; Sechi, G.M. Comparison of generic simulation models for water resource systems. Environ. Model. Softw. 2013, 40, 214-225. [CrossRef]

10. Wurbs, R.A. Comparative Evaluation of Generalized Reservoir/River System Models_Technical Report No. 282; Texas Water Resources Institute the Texas A\&M University System: College Station, TX, USA, 2005. 
11. Hatmoko, W.; Triweko, W.; Yudianto, D. Sistem pendukung keputusan untuk perencanaan alokasi air secara partisipatoris pada suatu wilayah sungai. Jurnal Teknik Hidraulik Puslitbang Sumber Daya Air-Departemen Pekerjaan Umum Republik Indonesia 2012, 3, 71-86.

12. Farriansyah, A.M.; Juwono, P.T.; Suhartanto, E.; Dermawan, V.; Alyaminy, R.S.Z. The Performance of Equalization Model of Water Allocation Inter Irrigation Areas in River System. In Proceedings of the Third International Conference on Sustainable Infrastructure and Built Environment, ITB, Bandung, Indonesia, 26-27 September 2017.

13. Farriansyah, A.M.; Corsel, A.R.; Novelia, G.R. Rekayasa model alokasi air tahunan Wilayah Sungai Lombok (Studi DAS Jangkok). In Proceedings of the 31st Indonesian Association of Hydraulic Engineers Annual Conference (PIT HATHI), Padang, Indonesia, 22-24 August 2014.

14. Farriansyah, A.M.; Novelia, G.R.; Husnan, B. Alokasi air real time (kasus: Sungai Jangkok). In Proceedings of the 32ndIndonesian Association of Hydraulic Engineers Annual Conference (PIT HATHI), Malang, Indonesia, 6-8 November 2015.

15. Mensik, P.; Stary, M.; Marton, D. Water Management Software for Controlling the Water Supply Function of Many Reservoirs in a Watershed. Water Resour. 2015, 42, 133-145. [CrossRef]

16. Kim, T.J.; Wurbs, R.A. Modeling river/reservoir system management with the expanded WRAP. KSCE J. Civ. Eng. 2011, 15, 1457-1467. [CrossRef]

17. Li, H.; Shao, D.; Xu, B.; Chen, S.; Gu, W.; Tan, X. Failure Analysis of a New Irrigation Water Allocation Mode Based on Copula Approaches in the Zhanghe Irrigation District, China. Water 2016, 8, 251. [CrossRef]

18. Farriansyah, A.M.; Aribowo, G.G. Adaptasi alokasi air akibat indikasi perubahan iklim dan kompleksitas sistem sumber daya air di Wilayah Sungai Pulau Lombok. In Proceedings of the 26thIndonesian Association of Hydraulic Engineers Annual Conference (PIT HATHI), Banjarmasin, Indonesia, 23-25 October 2009.

19. Kartabrata, M.; Marjanto, W.D. Penggunaan computer model untuk distribusi air dan alokasi air pada Water Operation Centre (WOC) Unit—Dinas Pekerjaan Umum Provinsi Nusa Tenggara Barat (NTB). Jurnal Informasi Teknik, Direktorat Jenderal Pengairan-Departemen Pekerjaan Umum Republik Indonesia 1994, 14, 46-60.

20. Hatmoko, W. Indeks kelangkaan air irigasi. In Proceedings of the Paper Conference of Indonesia's INACID, Palembang, Indonesia, 16-18 May 2014; Volume 1.

21. Rencana Alokasi Air Tahunan 2016/2017 dan Rencana Alokasi Air Tahunan 2017/2018 Wilayah Sungai Lombok; Balai Wilayah Sungai Nusa Tenggara I (BWS-NT I): Mataram, Lombok, Indonesia, 2016/2017.

22. Yazdeli, Y.B.; Haddad, O.B.; Mehdipour, E.F.; Mariño, M.A. Evaluation of real time operation rules in reservoir systems operation. Water Resour. Manag. 2014, 28, 715-729. [CrossRef]

23. Singh, A. Review: Computer-based models for managing the water-resource problems of irrigated agriculture. Hydrogeol. J. 2015, 23, 1217-1227. [CrossRef]

24. Guo, S.; Chen, J.; Li, Y.; Liu, P.; Li, T. Joint operation of the multi-reservoir system of the Three Gorges and the Qingiiang cascade reservoirs. J. Energies 2011, 4, 1036-1050. [CrossRef]

25. Haro, D.; Paredes, J.; Solera, A.; Andreu, J. A model for solving the optimal water allocation problem in river basins with network flow programming when introducing non-linearities. Water Resour. Manag. 2012, 26, 4059-4071. [CrossRef]

26. Koch, H.; Grunewald, U. A comparison of modelling systems for the development and revison of water resources management plans. Water Resour. Manag. 2008, 23, 1403-1422. [CrossRef]

27. Wegerich, K. A critical review of the concept of equity to support water allocation at various scales in the Amu Darya Basin. Irrig. Drain. Syst. 2007, 21, 185-195. [CrossRef]

28. Gorantiwar, S.D.; Smout, I.K. Performance Assessment of Irrigation Water Management of Heterogeneous Irrigation Schemes: 1. A Framework for Evaluation. Irrigation and Drainage Systems; Loughborough University's Institutional Repository: Leicestershire, UK, 2005.

29. Kundzewicz, Z.W.; Kindler, J. Multiple criteria for evaluation of reliability aspects of water resource systems. In Proceedings of the Modelling and Management of Sustainable Basin-scale Water Resource Systems (Proceedings of a Boulder Symposium), Boulder, CO, USA, 1-6 July 1995; IAHS Publ, No. 231. pp. 217-224.

30. Kelley, T.; Johnson, S.H., III. Technical Communication: Use of Factor-K Water Allocation System in Irrigation Management: Theory and Application in Indonesia. Water Resour. Manag. 1989, 3, 49-71. [CrossRef]

31. Peraturan Menteri Pekerjaan Umum dan Perumahan Rakyat Republik Indonesia No.12/PRT/M/2015 tentang Eksploitasi dan Pemeliharaan Jaringan Irigasi. Available online: http://birohukum.pu.go.id/ uploads/DPU/2015/PermenPUPR12-2015.pdf (accessed on 18 July 2018). 
32. Dutta, D.; Kima, S.; Vazea, J.; Hughesa, J.; Yanga, A. Water accounting for sustainable water resources management-Role of hydrological modelling. In Proceedings of the 21st International Congress on Modelling and Simulation, Canberra, Australia, 29 November-4 December 2015; A CSIRO Land and Water. pp. 2040-2046.

33. Gonzalez, J.F.; Decker, C.A.; Hall, J.W. A linear programming approach to water allocation during a drought. Water 2018, 10, 363. [CrossRef]

34. Meijer, K.S.; Krogt van der, W.N.M.; Beek van, E. A new approach to incorporating environmental flow requirements in water allocation modeling. Water Resour. Manag. 2012, 26, 1271-1286. [CrossRef]

35. Kriteria Perencanaan IrigasiKP-02; Direktorat Jenderal Sumber Daya Air, Departemen Pekerjaan Umum: Jakarta, Indonesia, 2013.

36. Farriansyah, A.M.; Novelia, G.R.; Husnan, B. The Development of Equalization Model of Water Allocation. In Proceedings of the 5th International Seminar HATHI, Bali, Indonesia, 29-31 July 2016.

37. Fayaed, S.S.; El-Shafie, A.; Jaafar, O. Reservoir-system simulation and optimization techniques. Stoch. Environ. Res. Risk Assess. 2013, 27, 1751-1772. [CrossRef]

38. Kafiansyah, M.Y. Simulasi Pola Operasi Waduk Pandanduri dengan Optimasi Faktor-K Irigasi. Skripsi; Departement of Water Resources Engineering-Universitas Brawijaya: Malang, Indonesia, 2017.

39. Shamim, M.A.; Hassan, M.; Ahmad, S.; Zeeshan, M. A comparison of artificial neuron network (ANN) and local linear regression (LLR) techniques for predicting monthly reservoir levels. KSCE J. Civ. Eng. 2015, 20, 971-977. [CrossRef]

40. Wang, T.; Fang, G.; Xie, X.; Liu, Y.; Ma, Z. A multi-dimensional equilibrium allocation model of water resources based on a groundwater multiple loop iteration technique. Water 2017, 9, 718. [CrossRef]

41. Hatmoko, W. Modeling of real time water allocation planning in Indonesia. In Proceedings of the 3rd Asian Regional Conference-ICID, Kuala Lumpur, Malaysia, 10-15 September 2006.

42. Hoff, H.; Bonzi, C.; Joyce, B.; Tielbörger, K. A water resources planning tool for the Jordan River Basin. Water 2011, 3, 718-736. [CrossRef]

43. Elmahdi, A.; Malano, H.; Etchells, T. Using system dynamics to model water-reallocation. Environmentalist 2007, 27, 3-12. [CrossRef]

44. Sargent, R.G. Verifying and validating simulation models. In Proceedings of the 2014 Winter Simulation Conference, Savannah, GA, USA, 7-10 December 2014. 